\title{
Regulation of GnRH receptor gene expression in sheep and cattle
}

\author{
A. M. Turzillo and T. M. Nett* \\ Animal Reproduction and Biotechnology Laboratory, Department of Physiology, Colorado State \\ University, Fort Collins, CO 80523, USA
}

The GnRH receptor plays a pivotal role in reproduction. This review summarizes current knowledge of the regulation of $\mathrm{GnRH}$ receptor gene expression by endocrine factors in sheep and cattle. Expression of the GnRH receptor gene, measured by steady-state amounts of GnRH receptor messenger RNA (mRNA), is maximal during the preovulatory period. The molecular events leading to maximal $\mathrm{GnRH}$ receptor gene expression are probably triggered by decreased circulating concentrations of progesterone at luteolysis. Because GnRI is a positive homologous regulator of its own receptor, increased pulsatile GnRH after removal of negative feedback effects of progesterone stimulates expression of the GnRH receptor gene early in the preovulatory period. Oestradiol is also a positive regulator of GnRH receptor gene expression, and increased serum concentrations of oestradiol from developing follicles probably maintain high abundance of $\mathrm{GnRH}$ receptor mRNA later in the preovulatory period. Since increased amount of GnRH receptor mRNA precedes maximal numbers of GnRH receptors before the LH surge, increased expression of the GnRH receptor gene is an important mechanism by which maximal sensitivity of gonadotrophs to GnRH is achieved. Future efforts should be directed towards elucidating the molecular mechanisms underlying transcriptional regulation of the $\mathrm{GnRH}$ receptor gene in ruminants by endocrine factors.

\section{Introduction}

The pituitary receptor for GnRH is a critical component of the reproductive axis. Interaction of GnRH with its receptor stimulates synthesis and secretion of the gonadotrophins that are essential for gonadal function. Numbers of GnRH receptors throughout the oestrous cycle have been characterized (Nett et al., 1987; Nett, 1990), and changes in numbers of GnRH receptors are believed to be important in regulating sensitivity of the anterior pituitary gland to GnRH (Wise et al., 1984). Until 1992, the structural characteristics of the GnRH receptor were unknown and molecular probes for examining regulation of the $\mathrm{GnRH}$ receptor gene were not available. Cloning of complementary DNAs (cDNAs) encoding the GnRH receptor in several species including domestic ruminants (Brooks et al., 1993; Kakar et al., 1993) has revealed the basic structure of this receptor. In mice and rats, the GnRH receptor cDNA encodes a 327 amino acid protein while the ovine, bovine, human and pig cDNAs encode 328 amino acids (reviewed by Sealfon et al., 1997). The GnRH receptor is believed to have seven transmembrane domains typical of $G$ protein-coupled receptors. However, the receptor is unique among $\mathrm{G}$ protein-coupled receptors in that it lacks a cytoplasmic $\mathrm{C}$-terminal tail (Sealfon et al, 1997). Isolation of these GnRH receptor cDNAs was an essential first step towards increasing understanding of the gene encoding the GnRH receptor, and led to a wide range of studies on the regulation of $\mathrm{GnRH}$ receptor gene expression.

This review will focus on the regulation of $\mathrm{GnRH}$ receptor gene expression by endocrine factors in ewes. At least four hormones are known to affect the ovine GnRH receptor gene: oestradiol, $\mathrm{GnRH}$, progesterone and inhibin. Evidence for regulation of GnRH receptor gene expression by each of these hormones during the oestrous cycle will be discussed. Although there is much less 
information available regarding $\mathrm{GnRH}$ receptor gene expression in the cow, findings from bovine studies are included where appropriate. Current efforts to elucidate molecular mechanisms underlying expression of the GnRH receptor gene in sheep are also discussed.

\section{GnRH Receptor Gene Expression During the Oestrous Cycle}

The most dynamic time during the oestrous cycle with respect to pituitary-ovarian interactions is the preovulatory period, when serum concentrations of progesterone decline as a result of luteolysis and serum concentrations of oestradiol and inhibin rise with development of the preovulatory follicle. This pattern of ovarian hormone secretion leads to important changes at the hypothalamus and a marked increase in release of GnRH (Moenter et al., 1991). Throughout the oestrous cycle in ewes and cows, pituitary concentrations of GnRH receptors change four-to tenfold (Nett et al., 1987; Nett, 1990). In ewes, numbers of GnRH receptors remain static during much of the luteal phase, but increase during the preovulatory period (Crowder and Nett, 1984; Brooks et al., 1993; Turzillo et al., 1994; Hamernik et al., 1995). It seems likely that this increase contributes to maximal sensitivity of gonadotrophs to GnRH at this time, and thus is an important step in the series of events leading to the ovulatory LH surge. To determine whether the large number of GnRH receptors during the preovulatory period is the result of increased expression of the GnRH receptor gene, several investigators have measured steady-state concentrations of GnRH receptor mRNA in ovine pituitary glands after induction of luteolysis (Fig. 1). Concentrations of GnRH receptor mRNA are increased as early as $12 \mathrm{~h}$ after luteolysis (Turzillo et al., 1994). Amounts of GrRH receptor mRNA remain high at $24 \mathrm{~h}$ and $48 \mathrm{~h}$ but return to pretreatment (luteal) values at $72 \mathrm{~h}$ and $96 \mathrm{~h}$ (Brooks et al., 1993; Hamernik et al., 1995). Amounts of GnRH receptor mRNA corresponded closely to numbers of GnRH receptors in each of these studies. In the early preovulatory period, increased GnRH receptor gene expression preceded an increase in the number of GnRH receptors (Fig. 1; Turzillo et al., 1994) and maximal numbers of GnRH receptors were observed later in the preovulatory period near the onset of the LH surge (Crowder and Nett, 1984; Hamernik et al., 1995). These temporal relationships support the hypothesis that increased amounts of ovine GnRH receptor mRNA lead to greater numbers of GnRH receptors which in turn maximize pituitary sensitivity to GnRH in preparation for the LH surge.

An increase in $\mathrm{GnRH}$ receptor gene expression has been observed during the preovulatory period in cows (A. M. Turzillo, T. M. Nett, A. Roberts and S. E. Echternkamp, unpublished). However, whether there are concomitant preovulatory increases in numbers of bovine GnRH receptors is unclear, since Leung et al. (1984) and Nett et al. (1987) did not observe higher concentrations of GnRH receptors during the preovulatory period compared with the luteal phase. However, in both studies, maximal concentrations of GnRH receptors were observed during prooestrus. A more detailed study in which pituitary glands are collected at several times after luteolysis is needed to clarify the relationship between GnRH receptor gene expression and numbers of GnRH receptors during the follicular phase in cows.

Collectively, these findings provide strong evidence that the increase in numbers of $\mathrm{GnRH}$ receptors during the preovulatory period in sheep and cattle are mediated by increased expression of the GnRH receptor gene. The next logical question is, what are the endocrine factors involved in stimulating GnRH receptor gene expression during the oestrous cycle? In the following sections, how changes in secretion of ovarian and hypothalamic hormones may affect expression of the GnRH receptor gene will be examined.

\section{The Role of Oestradiol}

The importance of oestradiol in regulating hypothalamic-pituitary physiology in ruminants is well documented. Treatment with oestradiol can induce an LH surge in ewes and cows, and one mechanism by which oestradiol exerts this effect is by stimulating hypothalamic secretion of GnRH. 


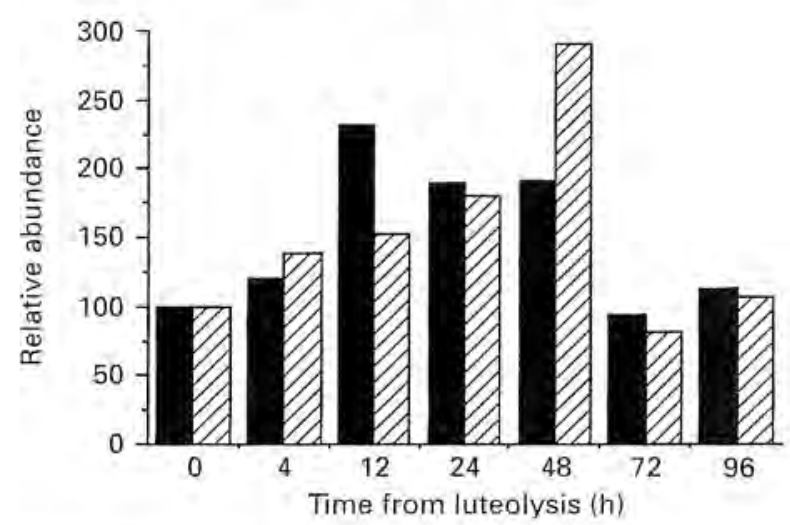

Fig. 1. Relative abundance of GnRH receptor mRNA (mean steady-state levels; ) and concentrations of $\mathrm{GnRH}$ receptors $(\measuredangle)$ in anterior pituitary tissue collected from ewes before and affer induction of luteolysis. Data were combined from Brooks et al. (1993); Turzillo et al. (1994); and Hamemik et al. (1995).

Oestradiol also has important effects on pituitary function and increases pituitary sensitivity to GnRH in ewes and cows, apparently by increasing numbers of GnRH receptors (Moss et al., 1981; Schoenemann et al., 1985; Turzillo et al, 1994; Hamernik et al., 1995). The stimulatory effect of oestradiol on numbers of GnRH receptors is evident in the absence of hypothalamic input, thus demonstrating a direct pituitary site of action (Gregg and Nett, 1989). Similar effects are observed in cultured ovine pituitary cells, in which oestradiol induces a two- to threefold increase in GnRHstimulated LH secretion (Huang and Miller, 1980; Moss and Nett, 1980) and increases numbers of GnRH receptors (Laws et al., 1990a; Gregg et al., 1990). More recently, it has been reported that oestradiol increases GnRH receptor gene expression in vivo (Turzillo et al., 1994; Hamernik et al., 1995), and this effect can occur in the absence of GnRH (Turzillo et al., 1995b; Adams et al., 1997) and in cultured ovine pituitary cells (Fig. 2; Wu et al., 1994). Because serum concentrations of oestradiol increase markedly during the preovulatory period, these observations appear to indicate that oestradiol is the endocrine factor responsible for increasing GnRH receptor gene expression before the ovulatory LH surge, which in turn leads to greater numbers of GnRH receptors on gonadotrophs.

Although the importance of oestradiol during the preovulatory period is indisputable, there is evidence to indicate that oestradiol may not be the endocrine factor responsible for initiating the events leading to maximal numbers of GnRH receptors. To characterize the temporal relationships among GnRH receptor gene expression and endocrine changes during the early preovulatory period, we measured serum concentrations of oestradiol and progesterone and amounts of GnRH receptor mRNA in ewes during the $24 \mathrm{~h}$ after induction of luteolysis with prostaglandin $\mathrm{F}_{2 a}\left(\mathrm{PGF}_{2 a}\right.$; Turzillo et al., 1994). Concentrations of GnRH receptor mRNA were increased at $12 \mathrm{~h}$ after treatment with $\mathrm{PGF}_{2 \alpha}$. This increase was associated with a $50 \%$ decrease in circulating concentrations of progesterone, but occurred before serum concentrations of oestradiol began to rise (Fig. 3). Thus it appears that the initial molecular events leading to increased expression of the GnRH receptor gene during the early preovulatory period in ewes do not require increased pituitary exposure to oestradiol, but instead are associated more closely with decreased concentrations of progesterone. Oestradiol probably maintains increased $\mathrm{GnRH}$ receptor gene expression later in the preovulatory period. Therefore, progesterone may exert negative effects on GnRH receptor gene expression during the oestrous cycle, which led us to consider the potential mechanisms underlying this effect of progesterone. 


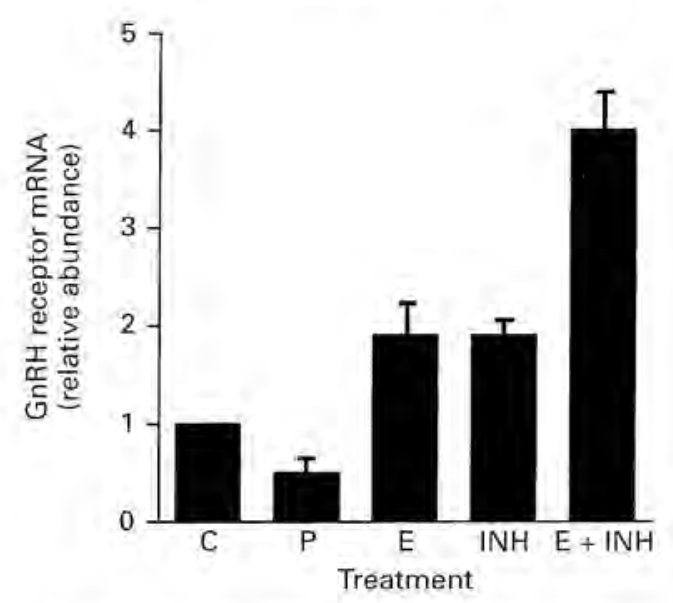

Fig. 2. Mean ( \pm SEM) concentrations of GnRH receptor mRNA in cultured ovine pituitary cells treated for $48 \mathrm{~h}$ with control medium (C), progesterone (P; $\left.100 \mathrm{nmol} \mathrm{I}^{-1}\right)$, oestradiol (E; $10 \mathrm{nmol}$ $\mathrm{I}^{-1} \mathrm{i}$, an enriched preparation of porcine follicular inhibin (INH; equivalent to $10 \mathrm{ng} \mathrm{m} \mathrm{m}^{-1}$ pure $32 \mathrm{kDa}$ porcine inhibin), or the combination of $\mathrm{E}+\mathrm{INH}$. Adapted from Wu et al (1994)

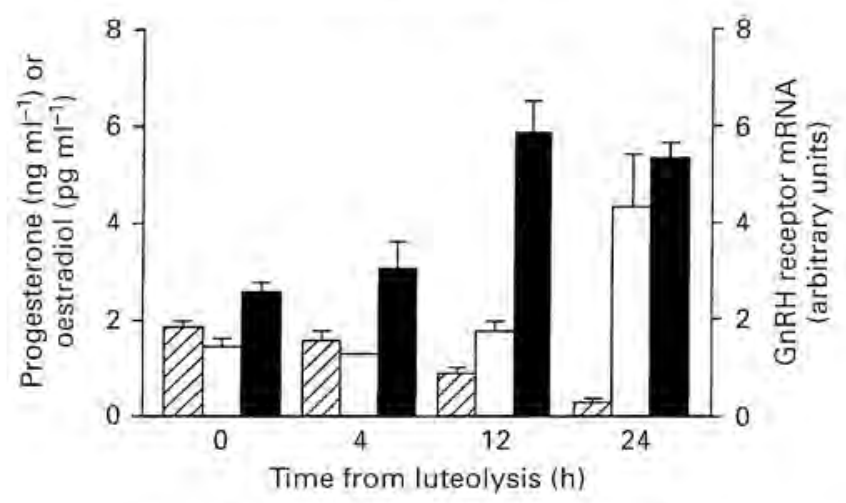

Fig. 3. Concentrations of progesterone $(\square)$ and oestradiol $(\square)$ in serum and GnRH receptor mRNA in pituitary tissue ( $\mathbf{D})$ collected from ewes $0 \mathrm{~h}, 4 \mathrm{~h}, 12 \mathrm{~h}$ and $24 \mathrm{~h}$ after induction of luteolysis with $\mathrm{PGF}_{2 \alpha^{\circ}}$. Data are means \pm SEM. Note that increased concentrations of GnRH receptor mRNA at $12 \mathrm{~h}$ occurred before serum concentrations of oestradiol were increased and were associated with a $50 \%$ decrease in serum concentrations of progesterone. Adapted from Turzillo et al. (1994).

\section{Progesterone: A Negative Regulator of GnRH Receptor Gene Expression}

Several lines of evidence implicate progesterone as a negative regulator of ovine GnRH receptor gene expression. First, numbers of GnRH receptors and expression of the GnRH receptor gene are relatively low during the luteal phase when concentrations of progesterone are maximal, and 


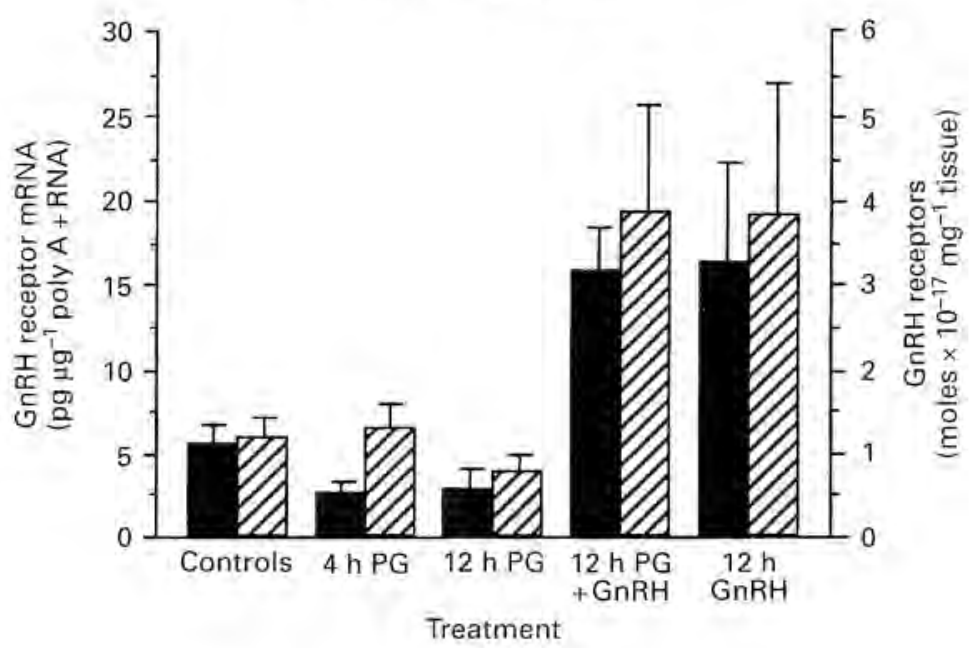

Fig. 4. Pituitary concentrations of GnRH receptor mRNA ( $\boldsymbol{\square})$ and GnRH receptors $(\square)$ in ewes during the anoestrous season. Follicular growth and ovulation were stimulated pharmacologically, and luteolysis was induced 11 or 12 days later with $\mathrm{PGF}_{2 \mathrm{e}^{+}}$Pituitary tissues were collected $4 \mathrm{~h}$ or $12 \mathrm{~h}$ after treatment with $\mathrm{PGF}_{2 n}(\mathrm{PG}), 12 \mathrm{~h}$ after treatment with $\mathrm{PGF}_{2 \mathrm{a}}$ and $\mathrm{GnRH}$ (12 h $\mathrm{PG}+\mathrm{GnRH})$, or $12 \mathrm{~h}$ after treatment with $\mathrm{GnRH}$ only (12 h GnRH). GnRH was administered at intervals of $1 \mathrm{~h}$. Control ewes were not treated with $\mathrm{PGF}_{2 a}$ or GnRH. Data are means \pm SEM. Adapted from Turzillo et al. (1995b).

increase when progesterone falls during the demise of the corpus luteum. Second, the stimulatory effects of oestradiol on GnRH receptor gene expression and numbers of GnRH receptors are prevented during the luteal phase when endogenous progesterone is high (Brooks and McNeilly, 1994; Turzillo et al., 1998). The third line of evidence comes from a series of studies conducted in vitro. In cultured ovine pituitary cells, progesterone decreases responsiveness to GnRH (Batra and Miller, 1985), numbers of receptors for GnRH (Laws et al, 1990b) and amounts of mRNA encoding the GnRH receptor (Fig. 2; Wu et al., 1994). Furthermore, progesterone can attenuate the stimulatory effects of oestradiol on GnRH-stimulated LH secretion (Batra and Miller, 1985) and numbers of GnRH receptors (Sealfon et al, 1990) in vitro. From these studies it seems logical to hypothesize that progesterone has inhibitory effects on $\mathrm{GnRH}$ receptors in vivo, and that the decrease in circulating concentrations of progesterone at luteolysis removes this inhibition, allowing increased expression of the GnRH receptor gene followed by increased numbers of GnRH receptors.

There are at least two mechanisms by which progesterone might exert its effects on the GnRH receptor gene. One mechanism involves direct effects of progesterone on the pituitary gland. This mechanism seems plausible in the light of evidence that progesterone affects GnRH receptor gene expression in vitro, in the absence of hypothalamic influences. Alternatively, progesterone might regulate the $\mathrm{GnRH}$ receptor gene indirectly via negative feedback effects on secretion of GnRH. Decreasing concentrations of progesterone during luteolysis lead to increased pulsatile secretion of GnRH. As discussed later, GnRH is an important regulator of its own receptor and pulsatile GnRH increases the number of GnRH receptors in ewes (Khalid et al., 1987; Hamernik and Nett, 1988; Turzillo et al., 1995b). Therefore, increased stimulation of the pituitary gland by GnRH during luteolysis could lead to increased expression of the GnRH receptor gene.

To determine whether progesterone affects $\mathrm{GnRH}$ receptor gene expression in vivo directly at the pituitary or indirectly via increased GnRH secretion, we designed an experiment in which decreased concentrations of progesterone could be achieved without a concurrent rise in pulsatile GnRH (Turzillo et al., 1995b). Ovulation and subsequent luteal formation were induced in anoestrous ewes: and luteolysis was initiated on day 11 or 12 of the induced oestrous cycle. Because of photoperiodic 
inhibition of the GnRH pulse generator during anoestrus, an increase in GnRH secretion following luteolysis did not occur in this experimental model. If effects of progesterone on GnRH receptor gene expression occur directly at the pituitary gland and are independent of $\mathrm{GnRH}$, decreasing concentrations of progesterone in this model should result in increased amounts of GnRH receptor mRNA. This was not the case (Fig. 4). In contrast, when pulsatile GnRH was administered each hour for $12 \mathrm{~h}$ after induction of luteolysis, concentrations of $\mathrm{GnRH}$ receptor mRNA were increased. This effect of GnRH was also obvious in ewes in which luteolysis was not induced and serum concentrations of progesterone remained high (Fig. 4). From these results, we conclude that the increase in $\mathrm{GnRH}$ receptor $\mathrm{mRNA}$ during the early preovulatory period is mediated by an indirect mechanism involving decreased negative feedback of progesterone on pulsatile hypothalamic $\mathrm{GnRH}$ secretion. Increased stimulation of the pituitary gland by $\mathrm{GnRH}$ then causes heightened expression of the GnRH receptor gene, thus initiating the molecular events that lead to increased concentrations of GnRH receptor mRNA and synthesis of GnRH receptors before the LH surge.

\section{Homologous Regulation by GnRH}

GnRH is secreted from the ovine hypothalamus in a pulsatile fashion and the importance of this pattern of GnRH secretion to pituitary function is well established. A marked increase in GnRH release occurs during the follicular phase in ewes (Moenter et al., 1991), and this increase is required for a normal LH surge. In addition to stimulating pulsatile LH secretion during the preovulatory period, GnRH is also a homologous regulator of its own receptor and probably serves to increase numbers of GnRH receptors before the ovulatory LH surge. Sheep have been used to develop several excellent experimental paradigms to study the regulation of $\mathrm{GnRH}$ receptors by $\mathrm{GnRH}$. One of these paradigms takes advantage of the large size of sheep, which allows surgical disconnection of the hypothalamus from the pituitary gland (hypothalamic-pituitary disconnection, HPD). This procedure effectively deprives the pituitary gland of GnRH (and other hypothalamic hormones), but does not interfere with the hypophyseal blood supply and allows the pituitary gland to remain viable despite the absence of hypothalamic input. In ovariectomized ewes, HPD results in decreased numbers of GnRH receptors (Clarke et al., 1987; Gregg and Nett, 1989; Turzillo et al., 1995a) which can be restored by treatment with pulsatile GnRH (Clarke et al., 1987; Hamernik and Nett, 1988). Significant reductions in numbers of $\mathrm{GnRH}$ receptors also occur when the pituitary gland is deprived of GnRH using non-surgical methods. Brooks and McNeilly (1994) observed decreased numbers of GnRH receptors after treating ewes during the oestrous cycle with an antagonist of GnRH, and Sakurai et al. (1997) reported similar results in wethers passively immunized against GnRH. From these studies, it is clear that continuous stimulation of the pituitary gland by GnRH is required to maintain normal numbers of GnRH receptors. However, there is some discrepancy regarding the effect of removing $\mathrm{GnRH}$ on $\mathrm{GnRH}$ receptor gene expression. Brooks and McNeilly (1994) and Sakurai et al. (1997) found that treatment of ovary-intact ewes with GnRH antagonist or passive immunization of wethers against $\mathrm{GnRH}$ resulted in decreased concentrations of $\mathrm{GnRH}$ receptor mRNA. This is in contrast to our observations in ovariectomized ewes in which amounts of GnRH receptor mRNA did not change significantly during the 3 days after HPD (Turzillo et al,, 1995a) or 6 days after passive immunization against GnRH (Turzillo and Nett, 1997). Although reasons for the lack of agreement among these studies are not obvious, the disparate results may be due to the use of different experimental models and the time after removal of GnRH when measurements were made.

Despite different effects of removing GnRH on GnRH receptor gene expression, administration of pulsatile GnRH to GnRH-deficient anoestrous ewes increased pituitary amounts of GnRH receptor mRNA (Turzillo et al,, 1995b) and numbers of GnRH receptors (Khalid et al., 1987; Hamernik and Nett, 1988; Turzillo et al., 1995b). These observations strengthen the claim that pulsatile GnRH is a positive regulator of GnRH receptor gene expression.

Information regarding effects of pulsatile GnRH on bovine GnRH receptors is limited. Numbers of $\mathrm{GnRH}$ receptors were increased by pulsatile $\mathrm{GnRH}$ in prepubertal bull calves (Rodriguez and 
Wise, 1991) but in nutritionally anoestrous cows, treatment with pulsatile GnRH did not affect pituitary concentrations of GnRH receptors or GnRH receptor mRNA (Vizcarra et al., 1997). Because secretion of LH is reduced in nutritionally anoestrous cows (Richards et al., 1989), it is presumed that release of $\mathrm{GnRH}$ is also reduced. However, it is possible that the decrease in GnRH caused by nutritional restriction in the study of Vizcarra et al. (1997) was sufficient to affect LH secretion but not GnRH receptors. This result could explain why treatment with exogenous GnRH pulses was ineffective in stimulating further increases in pituitary concentrations of GnRH receptors or GnRH receptor $\mathrm{mRNA}$.

Collectively, the bulk of evidence indicates that pulsatile stimulation by GnRH is required to maintain tissue concentrations of GnRH receptor and GnRH receptor mRNA in the ruminant pituitary gland. Therefore, marked increases in $\mathrm{GnRH}$ secretion probably play an important role in upregulation of $\mathrm{GnRH}$ receptors during the preovulatory period.

It is important to note that effects of $\mathrm{GnRH}$ on $\mathrm{GnRH}$ receptors differ markedly depending on the pattern of GnRH administration. After continuous exposure to GnRH, the anterior pituitary gland becomes refractory to further challenge with GnRH in ewes (Nett et al., 1981) and cows (Lamming and McLeod, 1988). This desensitization is marked by decreased tissue concentrations of GnRH receptors (Nett et al., 1981; Crowder et al., 1986; Vizcarra et al., 1997) and GnRH receptor mRNA (Vizcarra et al., 1997; Turzillo et al., 1998). Similarly, chronic treatment of ewes or wethers with GnRH agonists causes downregulation of $\mathrm{GnRH}$ receptors and reduces $\mathrm{GnRH}$ receptor gene expression (Brooks and McNeilly, 1994; Wu et al., 1994). GnRH receptors are internalized after binding GnRH (Hazum et al., 1980), and it is likely that the reduction in numbers of GnRH receptors induced by continuous GnRH treatment reflects this internalization. However, recent observations that decreased $\mathrm{GnRH}$ receptor gene expression occurs in conjunction with downregulation of GnRH receptors provide evidence that pituitary desensitization following continuous exposure to GnRH is mediated by reduced de novo synthesis of $\mathrm{GnRH}$ receptors as well as by internalization of existing GnRH receptors on gonadotrophs. These findings may have important physiological relevance. Secretion of GnRH increases 40-fold during the preovulatory period in ewes, and remains high for several hours after the LH surge (Moenter et al, 1991). Since concentrations of GnRH receptor mRNA and numbers of GnRH receptors decrease after the LH surge (Crowder and Nett, 1984; Hamernik et al., 1995), we speculate that termination of the LH surge may be due to pituitary desensitization mediated by decreased $\mathrm{GnRH}$ receptor gene expression and downregulation of GnRH receptors caused by extended exposure to high concentrations of GnRH.

\section{Does Inhibin Regulate GnRH Receptor Gene Expression?}

Inhibin is a gonadal peptide that selectively suppresses secretion of FSH. Inhibin is secreted by large antral ovine and bovine follicles, and increases in circulating concentrations of inhibin during the follicular phase in sheep and cattle have been reported (Padmanabhan et al., 1984; Findlay et al., 1990). Therefore, like oestradiol, ovarian inhibin may be an important endocrine regulator of pituitary function during the preovulatory period. Evidence that inhibin may affect $\mathrm{GnRH}$ receptors comes from studies conducted in vitro. In cultured ovine pituitary cells, inhibin enhanced GnRHstimulated secretion of LH (Miller and Huang, 1985; Muttukrishna and Knight, 1990), increased numbers of GnRH receptors (Laws et al, 1990b; Gregg et al., 1991) and increased amounts of GnRH receptor mRNA (Fig. 2; Wu et al., 1994). In the study by Wu et al. (1994), the combination of oestradiol and inhibin resulted in an additive effect on amounts of GnRH receptor mRNA. Positive effects of inhibin in vitro support the hypothesis that increasing concentrations of inhibin during the preovulatory period contribute to increased $\mathrm{GnRH}$ receptor gene expression and greater numbers of $\mathrm{GnRH}$ receptors observed during this time. However, there is no evidence to suggest that inhibin regulates GnRH receptors in vivo. In fact, treatment of ewes during the luteal phase for 4 or 9 days with bovine or ovine follicular fluid as a source of inhibin did not affect tissue concentrations of GnRH receptors or GnRH receptor mRNA (Brooks et al., 1992; Brooks and McNeilly, 1994), Similarly, we observed no changes in numbers of $\mathrm{GnRH}$ receptors or $\mathrm{GnRH}$ receptor gene expression in 


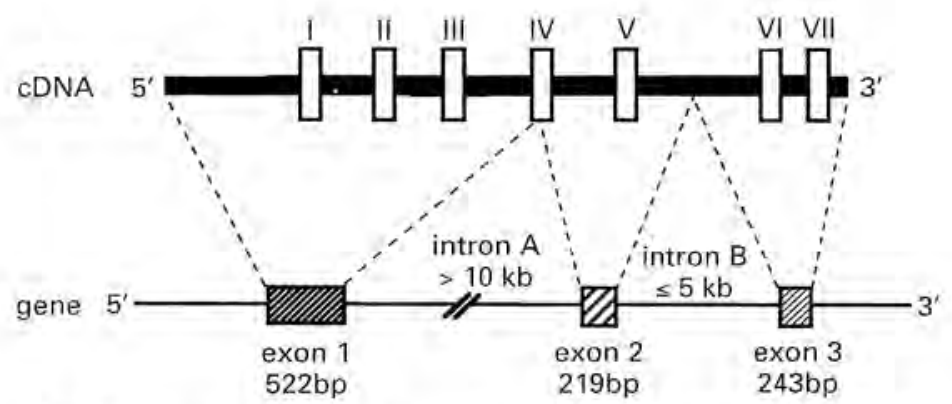

Fig. 5. Illustration of complementary DNA (CDNA) and gene encoding the ovine GnRH receptor. Transmembrane domains of the cDNA are represented by roman numerals I-VIL. The coding sequence of the receptor is divided among three exons and two introns. Sizes of exons and introns are indicated in base pairs (bp) or kilobases $(k b)$, respectively. (Reproduced with permission from Campion et al, , 1996).

ovariectomized ewes treated with bovine follicular fluid (Turzillo and Nett, 1997). The absence of an effect of treatment with bovine follicular fluid cannot be explained by a lack of inhibin bioactivity since serum concentrations of FSH and pituitary amounts of mRNA encoding FSH $\beta$ subunit were reduced $\geq 70 \%$ and $90 \%$, respectively. Collectively, the results of studies conducted in vivo do not support the idea that inhibin is an endocrine regulator of GnRH receptors. Reasons for the lack of agreement between findings obtained in vitro versus in vivo are unclear, but may be related to the potential role of inhibin as an intra-pituitary regulatory factor. Inhibin subunits are produced in rat gonadotrophs (Roberts et al., 1988), and local production of these subunits may be involved in transcriptional activation of the GnRH receptor gene (Fernandez-Vazquez et al., 1996). Whether there is a functional system involving paracrine or autocrine actions or inhibin in the ruminant pituitary gland is not yet certain. However, it is possible that the effects of inhibin on numbers of GnRH receptors and $\mathrm{GnRH}$ receptor gene expression in vitro may reflect intra-pituitary regulation rather than endocrine effects of inhibin of ovarian origin.

\section{The Gene Encoding Ovine GnRH Receptor}

From the preceding paragraphs, it is easy to understand how isolation of cDNAs encoding GnRH receptors has expanded knowledge of GnRH receptor gene expression in cattle and sheep. Concurrent with studies on the endocrine regulation of GnRH receptor gene expression, we became interested in exploring the molecular mechanisms underlying transcriptional regulation of the $\mathrm{GnRH}$ receptor gene in ruminants. To begin to address this issue, we cloned the ovine GnRH receptor gene (Fig. 5; Campion et al., 1996). This gene comprises three exons and two introns, and occurs as a single copy gene. Although there is considerable identity $(\geq 60 \%)$ between the nucleotide sequences of the proximal 5' flanking regions of the ovine and murine (Zhou et al., 1994; Clay et al., 1995) GnRH receptor genes, there are striking differences among species with respect to the DNA regulatory elements required for cell-specific expression. Transcriptional activity of the murine GnRH receptor gene is conferred by three cis-acting elements that lie within $500 \mathrm{bp}$ of the proximal promoter (Duval et al., 1997). These elements include an activating protein-1 (AP-1) binding site, presumably activated by the fos/jun family of transcription factors; a binding site for the orphan nuclear receptor, steroidogenic factor 1 (SF-1; reviewed by Parker and Schimmer, 1997); and GnRH receptor activating sequence, for which the trans-acting factor has yet to be identified. Of these three elements, only SF-1 appears to be a conserved mechanism for regulation of the ovine GnRH receptor promoter. Transcriptional activity of this promoter is increased following transient co-transfection of COS-7 cells with an expression vector for SF-1 (Quirk, 1997), indicating that SF-1 may regulate 


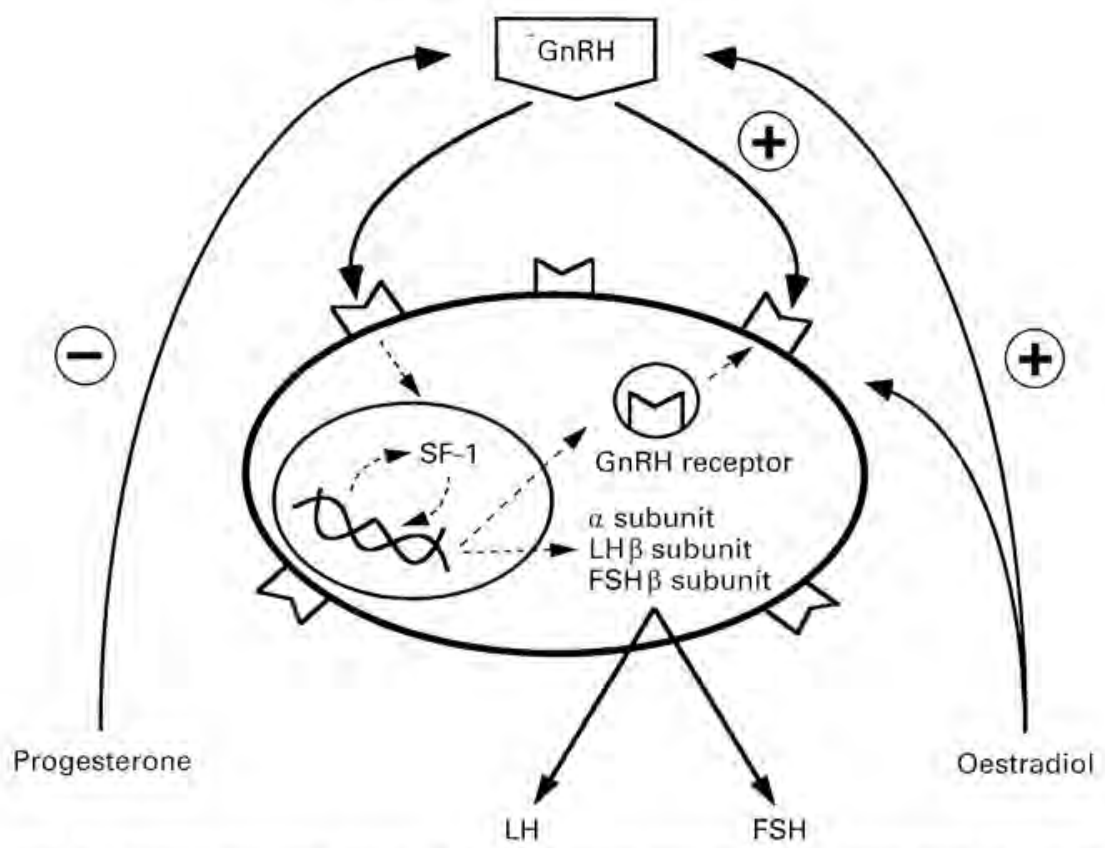

Fig. 6. Current working model of the endocrine and molecular regulation of $\mathrm{GnRH}$ receptor gene expression in gonadotrophs of domestic ruminants. Pulsatile GinRH from the hypothalamus stimulates GnRH receptor gene expression, and this effect appears to be modulated by negative feedback effects of progesterone from the corpus luteum. Oestradiol from the ovary also stimulates expression of the GnRH receptor gene. Although this effect of oestradiol is exerted directly on the pituitary gland, increased secretion of GnRH during positive feedback by oestradiol may also contribute to increased GnRH receptor gene expression. The transcription factor steroidogenic factor 1 (SF-1) may be an important regulator of several genes expressed by ruminant gonadotrophs, including the GnRH receptor gene. Increased expression of the GnRH receptor gene is believed to result in synthesis of GnRH receptors and their expression on the plasma membrane of gonadotrophs. Since interaction of GnRH with its receptor is absolutely necessary for synthesis of the gonadotrophin subunits $(\alpha$, LHB and FSH $\beta$, regulated expression of the GnRH receptor gene and synthesis of GnRH receptors are critical steps in the production of LH and FSH.

transcription of the GnRH receptor gene in sheep. In the light of evidence that SF-1 also regulates transcription of the bovine LH $\beta$ subunit gene (Keri and Nilson, 1996) and the gene for SF-1 is expressed in ovine gonadotrophs (Turzillo et al., 1997), SF-1 is emerging as a possible common transcriptional regulator of several genes that define the ruminant gonadotrope.

In addition to cell-specific expression, it is of interest to identify potential molecular mechanisms that mediate responsiveness of the $\mathrm{GnRH}$ receptor gene to endocrine factors. A DNA element that confers responsiveness of the ovine GnRH receptor gene to changes in concentrations of intracellular CAMP has been identified (C. M. Clay, personal communication). Transcriptional activity of the proximal promoter is increased in the presence of forskolin (a pharmacological activator of adenylyl cyclase), and this response appears to be mediated via a cAMP response element capable of binding cAMP response element binding protein. These findings implicate CAMP as a potential regulator of the GnRH receptor gene. In cultured ovine pituitary cells, binding of GnRH to ovine gonadotrophs increases CAMP and addition of a CAMP derivative can mimic the L.H-releasing effect of GnRH (Adams et al., 1979). Furthermore, treatment of rat pituitary cells with analogues of cAMP increased numbers of GnRH receptors (Young et al., 1984). Thus it is intriguing to speculate that the stimulatory effects of GnRH on tissue concentrations of GnRH receptor mRNA and GnRH receptors 
in sheep and cattle may be mediated at the molecular level by cAMP. Additional studies are needed to explore further the role of cAMP in regulation of GnRH receptor gene expression by $\mathrm{GnRH}$ and other endocrine factors.

\section{Conclusion}

Coordinated changes in sensitivity of the anterior pituitary gland to GnRH are required for normal reproductive cyclicity in cattle and sheep. Therefore, knowledge of the mechanisms regulating GnRH receptors is not only valuable to our basic understanding of pituitary function, but is also relevant to the development of improved methods for controlling fertility in domestic ruminants. We and others have characterized patterns of GnRH receptor gene expression and the endocrine regulation of these patterns during the oestrous cycle in sheep and cattle. It is clear that both hypothalamic $(\mathrm{GnRH})$ and ovarian hormones (progesterone and oestradiol) influence the expression of the GnRH receptor gene and numbers of GnRH receptors (Fig. 6). Because of the discrepancy regarding effects of inhibin on $\mathrm{GnRH}$ receptor gene expression in vitro versus in vivo, the role of ovarian inhibin as an endocrine regulator of the GnRH receptor gene in domestic ruminants remains uncertain. Recent evidence indicates that SF-1 may be a common transcriptional regulator of several genes expressed by gonadotrophs in domestic ruminants. Isolation of the gene encoding the ovine GnRH receptor will allow further study of the molecular mechanisms by which transcription of the GnRH receptor gene is influenced by changes in the endocrine milieu.

\section{References}

Adams BM, Sakurai H and Adams TE (1997) Effect of oestradiol on mRNA encoding GnRH receptor in pituitary tissue of orchidectomized sheep passively immunized against GnRH fournal of Reproduction and Fertility 111 207-212

Adams TE, Wagner TOF, Sawyer HR and Nett TM (1979) GnRH interaction with anterior pituitary. II Cyclic AMP as an intracellular mediator in the $\mathrm{GnRH}$ activated gonadotroph Biology of Reproduction 21 735-747

Batra SK and Miller WL (1985) Progesterone decreases the responsiveness of ovine pituitary cultures to luteinizing hormone-releasing hormone Endocrinology 117 1436-1440

Brooks J and McNeilly AS (1994) Regulation of gonadotropinreleasing hormone receptor mRNA expression in the sheep Joumal of Endocrinology 143 175-182

Brooks J, Crow WJ, MeNeilly JR and McNeilly AS (1992) Relationship between gonadotrophin subunit gene expression, gonadotrophin-releasing hormone receptor content and pituitary and plasma gonadotrophin concentrations during the rebound release of FSH after freatment of ewes with bovine follicular fluid during the luteal phase of the cycle Journal of Molecular Endocrinology 8109-118

Brooks J, Taylor PL, Saunders PTK, Eidne KA, Struthers WJ and McNeilly AS (1993) Cloning and sequencing of the sheep pituitary gonadotropin-releasing hormone receptor and changes in expression of its mRNA during the estrous cycle-Molecular and Cellular Endocrinology 94 R23-R27

Campion CE, Turzillo AM and Clay CM (1996) The gene encoding the ovine gonadotropin-releasing hormone (GnRH) receptor: cloning and initial characterization Gene $170277-280$

Clarke IJ, Cummins JT, Crowder ME and Nett TM (1987) Pituitary receptors for gonadotropin-releasing hormone in ovariectomized-hypothalamo pituitary disconnected ewes. I Effect of changing frequency of gonadotropinreleasing hormone pulses Biology of Reproduction 37 $749-754$
Clay CM, Nelson SM, DiGregorio GB, Campion CE, Wiedemann AL and Nett RJ (1995) Cell-specific expression of the mouse gonadotropin-releasing hormone (GnRH) receptor is conferred by elements residing within 500 bp of proximal 5 ' flanking region Endocrine 3 615-622

Crowder ME and Nett TM (1984) Pituitary content of gonadotropins and receptors for gonadotropin-releasing hormone $(\mathrm{GnRH})$ and hypothalamic content of GnRH during the periovulatory period of the ewe Endocrinology 114 234-239

Duval DL, Nelson SE and Clay CM (1997) The tripartite basal enhancer of the gonadotropin-releasing hormone ( $\mathrm{GnRH}$ ) receptor gene promoter regulates cell-specific expression through a novel $\mathrm{GnRH}$ receptor activating sequence Molecular Endocrinology 11 1814-1821

Fernandez-Vasquez G, Kaiser UB, Albarracin CT and Chin WW (1996) Transcriptional activation of the gonadotropinreleasing hormone receptor gene by activin A Molecular Endocrinology 10356-366

Findlay JK, Clarke IJ and Robertson DM (1990) Inhibin concentrations in ovarian and jugular venous plasma and the relationship of inhibin with follicle-stimulating hormone and futeinizing hormone during the ovine estrous cycle Endocrinology $126528-535$

Gregg DW and Nett TM (1989) Direct effects of estradiol-17ß on the number of gonadotropin-releasing hormone receptors in the ovine pituitary Biology of Reproduction $40288-293$

Gregg DW, Allen MC and Nett TM (1990) Estradiol-induced increase in number of gonadotropin-releasing hormone receptors in cultured ovine pituitary cells Biology of Reproduction 43 1032-1036

Gregg DW, Schwall RH and Nett TM (1991) Regulation of gonadotropin secretion and number of gonadotropinreleasing hormone receptors by inhibin, activin-A and estradiol Biology of Reproduction 44 725-732

Hamernik DL and Nett TM (1988) Gonadotropin-releasing hormone increases the amount of messenger ribonucleic 
acid for gonadotropins in ovariectomized ewes after hypothalamic-pituitary disconnection Endocrinology 122 959-966

Hamernik DL., Clay CM, Turzillo AM, VanKirk EA and Moss GE (1995) Estradiol increases amounts of messenger ribonucleic acid for gonadotropin-releasing hormone receptors in sheep Biology of Reproduction 53 179-185

Hazum E, Cuatrecasas PP, Marian J and Conn PM (1980) Receptormediated internalization of fluorescent gonadotropinreleasing hormone by pituitary gonadotropes Proceedings of the National Academy of Sciences LSA 77 6692-6695

Huang ES and Miller WL (1980) Effects of estradiol-17 $\beta$ on basal and luteinizing hormone releasing hormone-induced secretion of luteinizing hormone and follicle stimulating hormone by ovine pituitary cell culture Biology of Reproduction 23 124-134

Kakar SS, Rahe $\mathrm{CH}$ and Neill JD (1993) Molecular cloning, sequencing and characterizing the bovine receptor for gonadotropin releasing hormone (GnRH) Donrestic Animal Endocrinology 10 335-342

Keri RA and Nilson JH (1996) A steroidogenic factor-1 binding site is required for activity of the luteinizing hormone $b$ subunit promoter in gonadotropes of transgenic mice Journal of Biological Chemistry 271 10782-10785

Khalid M, Haresign W and Hunter MG (1987) Pulsatile GnRH administration stimulates the number of pituitary $\mathrm{GnRH}$ receptors in seasonally anoestrous ewes journal of Reproduction and Fertility 79 223-230

Lamming GE and McLeod BJ (1988) Continuous infusion of $\mathrm{GnRH}$ reduces the $\mathrm{LH}$ response to an intravenous $\mathrm{GnRH}$ injection but does not inhibit endogenous LH secretion in cows Journal of Reproduction and Feritility 82 237-246

Laws SC, Webster JC and Miller WL (1990a) Estradiol alters the effectiveness of gonadotropin-releasing hormone ( $\mathrm{GnRH}$ ) in ovine pituitary cultures: $\mathrm{GnRH}$ receptors versus responsiveness to GnRH Endocrinology 127 381-386

Laws SC, Beggs MJ, Webster JC and Miller WL (1990b) Inhibin increases and progesterone decreases receptors for gonadotropin-releasing hormone in ovine pituitary cell culture Endocrinology 127 373-380

Leung K, Padmanabhan V, Convey EM, Short RE and Staigmiller RB (1984) Relationship between pituitary responsiveness to $\mathrm{Gn}-\mathrm{RH}$ and number of Gn-RH-binding sites in pituitary glands of beef cows Journal of Reproduction and Fertility 71 $267-277$

Miller WL and Huang ES (1985) Secretion of ovine luteinizing hormone in vitro: differential positive control by $17 \beta-$ estradiol and a preparation of porcine ovarian inhibin Endocrinology 117 907-911

Moenter SM, Caraty A, Locatelli A and Karsch F (1991) Pattern of gonadotropin-releasing hormone (GnRH) secretion leading up to ovulation in the ewe existence of a preovulatory GnRH surge Endocrinology 129 1175-1182

Moss GE and Nett TM (1980) GnRH interaction with anterion pituitary. IV. Effect of estradiol-17ß on GnRH-mediated release of $\mathrm{L}, \mathrm{H}$ from ovine pituitary cells obtained during the breeding season, anestrous season, and period of transition into or out of the breeding season Biology of Reproduction $23398-403$

Moss GE, Crowder ME and Nett TM (1981) GnRH-receptor interaction. VI. Effect of progesterone and estradiol on hypophyseal teceptors for GnRH, and serum and hypophyseal concentrations of gonadotropins in ovariectomized ewes Biology of Reproduction 25 938-944
Muttukrishna S and Knight PG (1990) Effects of crude and highly purified bovine inhibin ( $\mathrm{Mr} 32,000$ form) on gonadotrophin production by ovine pituitary cells in vitro: inhibin enhances gonadotrophir-releasing hormoneinduced release of LH Journal of Endocrinology 127 149-159

Nett TM (1990) Regulation of genes controlling gonadotropin secretion fournal of Animal Science 68 (Supplement 2) 3-17

Nett TM, Crowder ME, Moss GE and Duello TM (1981) GnRH receptor interaction. V. Down-regulation of pitutitary receptors for $\mathrm{GnRH}$ in ovariectomized ewes by infusion of homologous hormone Biology of Reproduction 24 1145-1155

Nett TM, Cermak D, Braden T, Manns J and Niswender G (1987) Pituitary receptors for GnRH and estradiol, and pituitary content of gonadotropins in beef cows. I. Changes during the estrous cycle Domestic Animal Endocrinology 4 123-132

Padmanabhan V, Convey EM, Roche JF and Ireland JJ (1984) Changes in inhibin-like bioactivity in ovulatory and atretic follicles and utero-ovarian venous blood and prostaglandin-induced luteolysis in heifers Endocrinology 115 1332-1340

Parker KL and Schimmer BP (1997) Steroidogenic factor 1: A key determinant of endocrine development and function Endocrine Reviews 18 361-377

Quirk CC (1997) Cloning and Characterization of the Murine and Ovine Gonadotropin-releasing Hormone Receptor Genes PhD Dissertation, Colorado State University, Fort Collins

Richards MW, Wetteman RP and Schoenemann HM (1989) Nutritional anestrus in beef cows: body weight change, body condition, luteinizing hormone in serum and ovarian activity loumal of Animal Seience 67 1520-1526

Roberts V, Meunier H, Vaughn J, Rivier J, Rivier C, Vale $W$ and Sawchenko P (1988) Production and regulation of inhibin subunits in pituitary gonadotropes Endocrinology 124 552-554

Rodriguez RE and Wise ME (1991) Advancement of postnatal pulsatile luteinizing hormone secretion in the bull calf by pulsatile administration of gonadotropin-releasing hormone during infantile development Biology of Reproduction 44 432-139

Sakurai H, Adams BM and Adams TE (1997) Concentration of gonadotropin-releasing hormone receptor messenger ribonucleic acid in pituitary tissue of orchidectomized sheep: effect of passive immunization against gonadotropin-releasing hormone Journal of Aximal Science 75 189-194

Schoenemann HM, Humphrey WD, Crowder ME, Nett TM and Reeves J (1985) Pituitary luteinizing hormone-releasing hormone receptors in ovariectomized cows after challenge with ovarian steroids Biology of Reproduction 32 574-583

Sealfon SC, Laws SC, Wu JC, Gillo B and Miller WL (1990) Hormonal regulation of gonadotropin-releasing hormone receptors and messenger RNA activity in ovine pituitary culture Molecular Endocrinology 4 1980-1987

Sealfon SC, Weinstein H and Millar RP (1997) Molecular mechanisms of ligand interaction with the gonadotropinreleasing hormone receptor Endocrine Reviews 18 180-205

Turzillo AM and Nett TM (1997) Effects of bovine follicular fluid and passive immunization against gonadotropin-releasing hormone $(\mathrm{GnRH})$ on messenger ribonucleic acid for GnRH receptor and gonadotropin subunits in ovariectomized ewes Biology of Reproduction 56 1537-1543

Turzillo AM, Campion CE, Clay CM and Nett TM (1994) Regulation of gonadotropin-releasing hormone (GnRH) receptor messenger ribonucleic acid and $\mathrm{GnRH}$ receptors 
during the early preovulatory period in the ewe Endocrinology 135 1353-1358

Turzillo AM, DiGregorio GB and Nett TM (1995a) Messenger ribonucleic acid for gonadotropin-releasing hormone receptor and numbers of gonadotropin-releasing hormone receptors in ovariectomized ewes after hypothalamicpituitary disconnection and treatment with estradiol Joumal of Animal Science 73 1784-1788

Turzillo AM, Juengel $\pi$ and Nett TM (1995b) Pulsatile gonadotropin-releasing hormone (GnRH) increases concentrations of GnRH receptor messenger ribonucleic acid and numbers of $\mathrm{GnRH}$ receptors during luteolysis in the ewe Biology of Reproduction 53 418-423

Turzillo AM, Quirk CC, Juengel JL, Nett TM and Clay CM (1997) Effects of ovariectomy and hypothalamic-pituitary disconnection on amounts of steroidogenic factor-1 mRNA in the ovine anterior pituitary gland Endocrine 6 251-256

Turzillo AM, Clapper JA, Moss GE and Nett TM (1998) Regulation of ovine GnRH receptor gene expression by progesterone and oestradiol fournal of Reproduction and Fertility 113 251-256

Turzillo AM, Nolan TE and Nett TM (1998) Regulation of gonadotrophin-releasing hormone (GnRH) receptor gene expression in sheep: interaction of $\mathrm{GnRH}$ and estradiol Endocrimology 139 4890-4894

Vizcarra JA, Wetteman RP, Braden TD, Turzillo AM and Nett TM (1997) Effect of gonadotropin-releasing hormone (GnRH) pulse frequency on serum and pituitary concentrations of luteinizing hormone and follicle-stimulating hormone, GnRH receptors, and messenger ribonucleic acid for gonadotropin subunits in cows Endocrinology 138 594-601

Wise ME, Nieman D, Stewart J and Nett TM (1984) Effect of number of receptors for gonadotropin-releasing hormone on the release of luteinizing hormone Biology of Reproduction 31 1007-1013

Wu JC, Sealfon SC and Miller WL (1994) Gonadal hormones and gonadotropin-releasing hormone $(\mathrm{GnRH})$ alter messenger ribonucleic acid levels for GnRH receptors in sheep Endocrinology 134 1846-1850

Young LS, Naik SI and Clayton RN (1984) Adenosine 3', $5^{\prime}$ monophosphate derivatives increase gonadotropinreleasing hormone receptors in cultured pituitary cells Endocrinology 114 2114-2122

Zhou W and Sealfon SC (1994) Structure of the mouse gonadotropin-releasing hormone receptor gene: variant transcripts generated by alternative processing DNA and Cell Biology 13 605-614 